\title{
Anti Necrotic and Anticlastogenic Effect of Aloe Vera Extract in Swiss Albino Mice
}

\author{
Ramesh Agrawal ${ }^{1 *}$, Shaheen Nagma ${ }^{2}$, Neha Agrawal ${ }^{2}$ \\ ${ }^{1}$ Research Department, Priyamvada Birla Cancer Research Institute, Satna \\ PIN 485005 M.P.; \\ ${ }^{2}$ Dept of Gynaecology and obstratics, N.S.C.B.Medical College, Jabalpur M.P.
}

*Correspondence: R.C. Agrawal, Email: rcagrawal60@yahoo.com, Phone No.: +91 9826949427, Fax No.: +917672 400200.

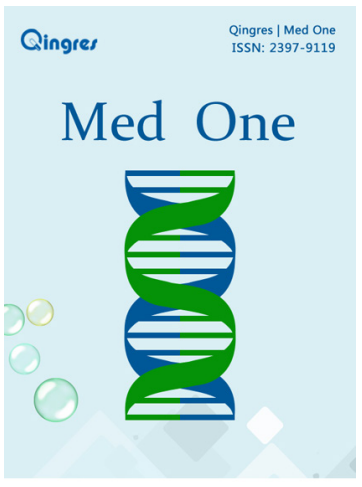

http://mo.qingres.com

\section{GOPEN ACCESS}

DOI: 10.20900/mo.20170020

Received: July 08, 2017

Accepted: September 10, 2017

Published: October 25, 2017

Copyright: @2017 Cain et al. This is an open access article distributed under the terms of the Creative Commons Attribution License, which permits unrestricted use, distribution, and reproduction in any medium, provided the original author and source are credited.

\begin{abstract}
Aloe vera $L$ ( $A$. barbadensis) is commonly used medicinal and cosmetic plant. In the present investigations the anti necrotic and anticlastogenic activity of Aloe vera extract was studied using Skin Papilloma, Melanoma Bone marrow micronucleus and chromosomal assays in Swiss albino and $\mathrm{C} 57 \mathrm{BI}$ mice. It has been observed that topical application of Aloe vera extract on the skin tumour induced by DMBA (7.12 Dimethyl Benz (a) nthracene) and croton oil have significantly reduced the tumour size, weight and histological changes as compared to control group. Antinecrotic activity was also observed in skin melanoma tumour induced by subcutaneous administration of B6 F10 cell lines in C57 BI mice. It reduced the tumour volume and increases the significant survival of animals as compared to control group. In anticlastogenic activity, Aloe vera extract have significantly prevented chromosomal aberrations and micronucleus formations in dose dependent manner. Results suggest the antinecrotic and anticlastogenic potential of Aloe vera extract in the above test systems.
\end{abstract}

Keywords: Anti Necrotic activity; Micronucleus assay; Chromosomal aberrations; Aloe vera; Melanoma; Papilloma

\section{INTRODUCTION}

In recent years, there have been considerable efforts to find naturally occurring substances that can inhibit, reverse, or retard mutagenesis. Wide arrays of substances present in the medicinal herbs or dietary plants have been screened for their ability to prevent mutagenicity [1]. Aloe vera L. (A. barbadensis) is used for several ailments. It belongs to the family Liliaceae. It is a popular household plant, found predominantly in dry localities in most parts of the world. A. vera is a rosette, long, slender, thick, fleshy leaves, like a smooth rubbery 
cactus. The contents of a leaf can be separated into 2 basic components i.e. gel and latex. Aloe gel contains glucomannan, acemannan, magnesium, glucose, linolenic acid, saponins, sterols, calcium, and cholesterols ${ }^{[2]}$, while aloe latex (leaf lining) contains anthraquinone glycosides such as aloe emodin, and barbaloin ${ }^{[3]}$. A vera has high concentrations of vitamins $\mathrm{A}, \mathrm{C}$, and $\mathrm{E}^{[4]}$ zinc $^{[5]}$ and amino acids, which are responsible for its usefulness in various pathological conditions. The acemanan of aloe has been used for topical treatment of wounds, minor burns, and skin irritation. Its Jel is commonly used on burns and minor cuts for enhancing the healing of dermal wounds ${ }^{[6]}$. Some recent studies have demonstrated the direct inhibitory effects of aloe extract and aloe gel on both tumor initiation and promotion. A polysaccharide fraction of aloe gel and aloe extract inhibited the binding of benzopyrene to primary rat hepatocytes and thus prevented the formation of potential cancer-initiating benzopyrene -DNA adducts ${ }^{[7]}$. In another study, aloe gel caused an induction of glutathione-S-transferase and inhibition of tumor promoting effects of phorbol myristic acetate ${ }^{[8]}$. These studies suggest a possible benefit of using aloe gel and aloe extract in cancer chemoprevention. Polysaccharides from aloe have shown radioprotective effects ${ }^{[9]}$. The alcoholic extract of Aloe vera has dose dependently inhibited gastric acid secretion ${ }^{[10]}$. Aloe emodin of Aloe vera have significantly inhibited MCC cells growth and possess specific toxicity to neuroectodermal cells ${ }^{[11]}$. Acemann a carbohydrate from Aloe vera has shown anti immune and anti tumoral activities ${ }^{[12]}$. The extract exhibited the best for radical scavenging activity [13]. Antinecrotic and anticlastogenic activity gel and extract have not been well reported previously therefore in these studies preventive effects of Aloe vera extract has been studied using skin Papilloma model, micronucleus and chromosomal tests.

\section{MATERIALS AND METHODS}

\subsection{Animals}

Random bred Swiss mice of the weight between 15-20 gms were collected from animal colony of PBCRI, Satna. The synthetic pellet diet was obtained from Golden feeds Ltd, Delhi and R.O. water were provided ad libitum. The Animal ethical approval was obtained before conduction of the experiments. The chemicals were procured from Sigma chemical co. USA and Ranbaxy co., Mumbai. The Aloe vera extract was prepared from the gel collected from leaves as described in our earlier paper (Agrawal et al, 2013).

\subsection{Antinecrotic effect of Aloe vera using Papilloma models}

These animals received single application of DMBA (100 Dg in $100 \mathrm{DI}$ acetone) (100 DI / mouse) and $1 \%$ croton oil in Acetone two weeks after the application of DMBA. The all tumour bearing animals were divided in four groups.

(a) Aloe vera treated group: The 4 tumour bearing animals were given topical application of 100DI of Aloe vera extract (dose of $500 \mathrm{mg} / \mathrm{kg}$ body wt.), 2 times in a week for 16 weeks;

(b) The 4 tumour bearing animals were kept as a control till 16 weeks. The animals of both groups were euthanized after 16 weeks and tumour size as well as weight were measured and tumour tissue were fixed in $10 \%$ formalin for histology.

\subsection{C57BL Melanoma Model}

I Group (Control): These animals received no treatment;

II Group (Cyclo+ Aloe vera extract): These animals received twice a week applications of Aloe vera extract $(500 \mathrm{mg} / \mathrm{kg})$ for one month + two applications of CP $(300 \mathrm{mg} / \mathrm{kg})$ for two weeks;

III Group (Aloe Vera extract Alone): These animals received twice a week applications of Aloe vera extract $(500 \mathrm{mg} / \mathrm{kg})$ for one month;

IV Group (Cyclophosphamide Alone): These animals received two applications of CP $(300 \mathrm{mg} / \mathrm{kg})$ for two weeks.

\subsection{Experimental Design}

The original cell lines (B16F10) were received from National Centre for Cell Science, Pune. These were maintained in our laboratory by serial transplantation of tumour cells by injecting 5 lakh cells subcutaneously to each mice for the induction of melanoma tumor. This method was performed as per the method reported by Oomman et. al. 1999 and standardized by us (Agrawal et al. 2009). The animals (C57BL mice) were divided into two groups comprises of 4 animals. When the tumor is grown up to $2-3 \mathrm{~cm}$. large, the animals were divided into different. Groups such as control and tested group and each group comprised of 4 animals. The treatment of Aloe vera extract was given orally at the dose of $500 \mathrm{mg} / \mathrm{kg}$. The survival rate was recorded. The data are represented in percentage survival of the animal, reduction in tumor volume, the life span of animals and total survival of animals. \% ILS $=$ (MST of control group-MST of experimental group/MST of 
control group) $-1 \times 100$ whereas. The inhibition rate of tumor. It was calculated by following formula: \% IR = 1- (Tumor volume of test group/Tumor volume of control group) $\times 100$. Statistical analysis was done using Students ' $\mathrm{t}$ ' test.

\subsection{Anticlstogenic studies}

The Antimutagenicity of Aloe vera extract was studied by chromosomal aberrations and micronuclei induction in the bone marrow cells of mice. For chromosomal aberrations assay method of Preston et al. ${ }^{[14]}$ and the method of Schmid ${ }^{[15]}$ for micronucleus assay and standardized by us was undertaken ${ }^{[16,17]}$. Aloe vera extract at the volume of $0.2 \mathrm{ml}$ was injected at different dose levels such as 250,500 and $750 \mathrm{mg} / \mathrm{kg}$ body weight 24 hours before the treatment of cyclophosphamide at the dose of $50 \mathrm{mg} / \mathrm{kg}$ body weight in $0.9 \%$ saline. Colchicines (4 mg/kg b.wt) was administered intraperitoneally 2 hours before the harvest of the cells. The slides were prepared essentially as per modified method of Preston et al ${ }^{[14]}$ for chromosomal aberrations and method of Schmid ${ }^{[15]}$ and standardized by us ${ }^{[16,17]}$. Both femur bone of mice were dissected out and the bone marrow was flushed out in HBBS solution as described earlier ${ }^{[16,17]}$. The smear was prepared in precleaned slides, air dried and fixed in absolute methanol. The slides were stained with Maygrunwald and Giemsa stain. The total no. of 2000 cells were counted and number of micronucleated polychromatic erythrocytes cells were scored. PCE: NCE ratio was also calculated. The data are presented in MNPCE \pm SE. The statistical significance was calculated using Student's 't' test.

\section{RESULTS}

The result showed the significant reduction of tumour size and weight as compared to control animals. The glutathione level in blood and liver showed significant increase as compared to control mice. The histology also showed reduced lessons and no advance changes leading to malignancy were observed in Aloe vera treated mice (Table 1).

Table 1. Tumour necrotic effect of Aloe vera extract

\begin{tabular}{lcccc}
\hline Group & $\begin{array}{c}\text { Tumour Size } \\
(\mathrm{cm})\end{array}$ & $\begin{array}{c}\text { Tumour weight } \\
(\mathrm{mm})\end{array}$ & $\begin{array}{c}\text { Glutathione level } \\
(\text { Blood })\end{array}$ & $\begin{array}{c}\text { Glutathione level } \\
\text { ( Liver })\end{array}$ \\
\hline Control (No treatment) & $1.08 \pm 0.65$ & $1111 \pm 795.57$ & $17.06 \pm 7.78$ & $31.35 \pm 10.24$ \\
Aloe vera treated & $0.575 \pm 0.095$ & $58.2 \pm 15.6$ & $49.56 \pm 19.38$ & $82.16 \pm 12.50$ \\
\hline
\end{tabular}

The findings of the present study on melanoma tumor model showed that the mice which received the treatment of Aqueous extract of Aloe vera at the dose of $750 \mathrm{mg} / \mathrm{kg}$ showed decreased Tumor volume of $2073.7 \pm 8.8 \mathrm{~mm}$ as compared to untreated group i.e. $3424.9 \mathrm{~mm}$. Whereas the survival of the above groups of animals were 20 days. When Aloe vera extract $(750 \mathrm{mg} / \mathrm{kg})$ in combination with Cyclophosphamide $(50 \mathrm{mg} / \mathrm{kg})$ was given orally to mice than the Tumor Volume observed was 2380.1 \pm 5.28 and Mean Survival days was 19 days. Cyclophosphamide alone showed the tumor volume of $2008.9 \pm 17.0$ but the mean survival days of Melanoma bearing mice were 13 days only. It seems that additive treatment of Aloe vera extract has increased the survival of the animals as compared to cyclophosphamide alone group. The histological sections of Melanoma tumor showed that maximum no. of viable cells and focal areas of necrosis were observed in untreated group. The group receiving Cyclophosphamide alone showed the presence of equal quantity of viable and necrotic cells. In combination, Cyclophosphamide with Aqueous extract of Aloe vera showed the maximum area covered by necrotic cells and few area of viable cells. It seems the more necrosis in the tumor cells represent the anticarcinogenic nature of Aloe vera leaves extract (Table 2 ). 
Table 2. Effect of Aloe vera Aqueous extract on Melanoma tumor bearing mice

\begin{tabular}{|c|c|c|c|c|c|c|}
\hline S. No & Groups & Treatment & $\begin{array}{l}\text { Tumor Volume } \\
(\mathrm{mm})\end{array}$ & $\begin{array}{l}\text { Survival } \\
\text { (Days) }\end{array}$ & $\begin{array}{l}\text { Increased Life } \\
\text { Span (\%) }\end{array}$ & $\begin{array}{l}\text { Inhibition } \\
\text { Rate (\%) }\end{array}$ \\
\hline 1. & 1 & Cyclo Alone $(50 \mathrm{mg} / \mathrm{kg})$ & $2008.9 \pm 17.0$ & 13 & $61.0 \pm 2.13$ & 41 \\
\hline 2. & II & Untreated & $3424.9 \pm 15.0$ & 17 & - & - \\
\hline 3. & III & $\begin{array}{l}\text { Aloe vera (Aqueous) } \\
(750 \mathrm{mg} / \mathrm{kg})\end{array}$ & $2073.7 \pm 8.8$ & 20 & $96.1 \pm 1.84$ & 40 \\
\hline 4 & VI & $\begin{array}{l}\text { Aloe vera }(750 \mathrm{mg} / \mathrm{kg}) \\
+ \text { Cyclo }(50 \mathrm{mg} / \mathrm{kg})\end{array}$ & $2380.1 \pm 5.28$ & 19 & $92.8 \pm 3.01^{*}$ & 30 \\
\hline
\end{tabular}

* denotes statistical significance as compared to untreated control at $p<0.05$ by student ' $\mathrm{t}$ ' test

The dose of 500 and $750 \mathrm{mg} / \mathrm{kg} \mathrm{b.wt} \mathrm{have}$ significantly prevented the micronucleus formation and chromosomal aberrations whereas $250 \mathrm{mg} /$ $\mathrm{kg}$ dose of aloe vera extract has prevented the micronucleus formation but it was not found statistically significant. The PCE/NCE ratio was not affected by Aloe vera extract treatment which shows no toxicity of the Aloe vera extract (Table $3 \& 4$ ).

Table 3. Effect of Aloe Vera ext. on micronucleus formation in mouse bone marrow cells

\begin{tabular}{lcc}
\hline Group & MNPCE + SERATIO & PCE/NCERATIO \\
\hline Cyclophosphamide $(50 \mathrm{~kg} / \mathrm{ml})$ & $4.6 \pm 1.18$ & $0.351 \pm 0.02$ \\
Aloe Vera Ext + CP $(250 \mathrm{mg} / \mathrm{kg}$ body wt) & $2.5 \pm 0.43$ & $0.363 \pm 0.03$ \\
Aloe Vera Ext + CP $(500 \mathrm{mg} / \mathrm{kg}$ body wt) & $1.67 \pm 0.33^{*}$ & $0.830 \pm 0.02^{*}$ \\
Aloe Vera Ext + CP $(750 \mathrm{mg} / \mathrm{kg}$ body wt) & $1.0 \pm 0.37^{*}$ & $0.08^{*}$ \\
Aloe Vera Ext. Alone $(250 \mathrm{mg} / \mathrm{kg}$ body wt) & $0.33 \pm 0.21$ & $0.948 \pm 0.02$ \\
Solvent (Water) & $0.45 \pm 0.03$ & 0.08 \\
\hline
\end{tabular}

denotes statistical significance in 't' test as compared to Cyclophosphamide treated group.

4 animals in each group. 
Table 4. Protection by Aloe vera extract against cyclophosphamide induced chromosomal aberrations

\begin{tabular}{|c|c|c|c|c|c|c|}
\hline & \multirow{2}{*}{$\begin{array}{l}\text { \%Chromo } \\
\text { aberrations }\end{array}$} & \multicolumn{4}{|c|}{ Types of Chromatid aberrations. } & \multirow{2}{*}{$\begin{array}{l}\% \text { Protection } \\
\text { by Aloe vera }\end{array}$} \\
\hline & & Break & Fragmentation & Association & Ring & \\
\hline $\begin{array}{l}\text { Cyclophosphamide } \\
(50 \mathrm{mg} / \mathrm{kg})\end{array}$ & $62.83 \pm 919$ & 31 & 18 & 12 & 4 & - \\
\hline $\begin{array}{l}\text { Aloe vera + Cyclo } \\
250 \mathrm{mg} / \mathrm{kg}+50\end{array}$ & $55.387 \pm 320$ & 20 & 2 & 8 & 1 & 11.86 \\
\hline $\begin{array}{l}\text { Aloe vera + Cyclo } \\
500 \mathrm{mg} / \mathrm{kg}+50\end{array}$ & $38.02 \pm 4.50$ * & 19 & 4 & 4 & 4 & 39.52 \\
\hline $\begin{array}{l}\text { Aloe vera + Cyclo } \\
750 \mathrm{mg} / \mathrm{kg}+50\end{array}$ & $37.22 \pm 1.79$ * & 13 & 7 & 11 & 3 & 40 \\
\hline $\begin{array}{l}\text { Aloe vera Alone } \\
500 \mathrm{mg} / \mathrm{kg}\end{array}$ & $13.4 \pm 5.89$ & 8 & 1 & 3 & - & - \\
\hline Solvent & $10.00 \pm 2.9$ & 5 & 6 & - & - & - \\
\hline
\end{tabular}

*Denotes statistical significance in 't' test as compared to Cyclophosphamide treated group, 4 animals was taken in each group.

\section{DISICUSSION}

The present study demonstrates the antinecrotic and antimutagenic potential of Aloe vera extract (AVE ) in male Swiss albino and in the C57 BI mice. Our previous study demonstrated that topical application of the AVE (500 mg/kg body weight) at the pre promotion phase showed a significant reduction in tumor incidence, tumor burden, tumor weight, tumor size, cumulative number of papillomas, in aloetreated groups relative to the carcinogen treated control $^{[18]}$. A polysaccharide fraction of aloe gel inhibited the binding of benzopyrene to primary rat hepatocytes and thus prevented the formation of potential cancer-initiating benzopyrene adducts ${ }^{[7]}$ . A follow-up study published showed that several other plant-derived polysaccharides were also able to block benzopyrene DNA adducts ${ }^{[8]}$. The several report suggest the components of Aloe vera such as Aloe emodin has induced unscheduled DNA synthesis in primary hepatocytes from male Wistar rats, micronucleus formation in mouse lymphoma L5178Y cells and TK6 human lymphoblastoid cells, and chromosomal aberrations in Chinese hamster ovary cells. Aloeemodin also inhibited topoisomerase
II, gave positive results in comet assays in mouse Iymphoma L5178Y cells, SCC-4 human tongue cancer cells, and NPC-039 human nasopharyngeal carcinoma cells, and transformed $\mathrm{C} 3 \mathrm{H} / \mathrm{M} 2$ mouse cells whereas Aloe vera inner leaf fillet Qmatrix did not induce chromosomal aberration in Chinese hamster lung cells in vitro; micronuclei were not formed in bone-marrow cells of mice treated orally in vivo ${ }^{[20]}$. In the prevention of mutagenicity reactive oxygen species may have role in the above systems ${ }^{[17]}$. Anti inflammatory,antihepatitis, and prevent gastric ulcer were reported. Anthraquinones of Aloe vera latex have shown cytotoxic and antiangiogenic effects $^{[19]}$. The present work suggests antinecrotic and anticlastogenic effect of Aloe vera extract in experimental mice.

\section{ACKNOWLEDGEMENTS}

The authors are thankful to Indian Council of Medical Research for providing financial assistance to carry out the above project work. The authors also thankful to Dr. S.K. Maheshwari Medical director of PBCRI, 
Satna for providing facilities to carry out the above work.

\section{CONFLICTS OF INTEREST}

The authors declare that they have no conflicts of interest.

\section{ABBREVIATIONS}

\author{
MST: Mean Survival Time \\ ILS: Increase Life Span \\ IR: Inhibitory Rate
}

\section{REFERENCES}

1. Surh YJ. Molecular mechanisms of chemo preventive effects of selected dietary and medical phenolic substances. Mutat Res. 1999; 428: 305-327.

2. Afzal M, Ali M. Identification of some prostanoids in Aloe vera extracts. Planta Med. 1991; 57: 3840.

3. Tyler V. Herbs of Choice: The Therapeutic Use of Phytomedicinals. Chromatographia. 2010; 71(9-10): 975-976

4. Atherton P. Aloe vera: magic or medicine? Nurs Stand. 1998; 12: 49-54.

5. Shelton RM. Aloe vera, its chemical and therapeutic properties. Int J Dermatol. 1991; 30: 679-683.

6. Chitra P, Sajith GB, Chandrasekaran G. Influence of Aloe vera on collagen turnover in healing of dermal wounds in rats. Indian J Exp Biol. 1998; 36: 896-901.

7. Kim H, Lee BM. Inhibition of benzo[a]pyreneDNA adduct formation by Aloe barbadensis Miller. Carcinogenesis. 1997; 18(4): 771-776.

8. Kim HS, Kecew S, Lee BM. Invitro chemopreventive effects of plant polysaccharides (Aloe barbadensis Miller, Lentinus edodes, Ganoderma lucidum, and Coriolus versicolor). Carcinogenesis. 1999; 20(8): 1637-1640.
9. Wang ZW, Zhou JM, Huang ZS, Yang AP, Liu ZC, Xia YF, Zeng YX, Zhu XF. Aloe Polysaccharides mediated radioprotective effect through the Inhibition of apoptosis. J Radiat Res. 2004; 45(3): 447-454.

10. Yusuf S, Agunu A, Diana M. The effect of Aloe vera $A$. Berger (Liliaceae) on gastric acid secretion and acute gastric mucosal injury in rats. J Ethnopharmacol. 2004; 93(1): 33-37.

11. Wasserman L, Avigad S, Beery E, Nordenberg $J$, Fenig $E$. The effect of aloe emodin on the proliferation of a new merkel carcinoma cell line. Am J Dermatopathol. 2002; 24(1): 17-22.

12. Lee JK, Lee MK, Yun YP, Kim Y, Kim JS, Kim YS, Kim K, Han SS, Lee CK. Acemannan purified from Aloe vera induces phenotypic and functional maturation of immature dendritic cells. Int Immunopharmacol. 2001; 1(7): 1275-1284.

13. Morse MA, Stoner GDCancer chemoprevention principles and prospects. Carcinogenesis. 1993; 14(9): 1737-1746.

14. Preston JR, Dean JB, Galloway S, Holden $\mathrm{H}$, MeFee FA, Shelby M. Mammalian in vivo cytogenetic assays, Analysis of chromosomal aberrations in mouse bone marrow cells. Mutat Res. 1987; 189(2): 157-165.

15. Schmid W. The micronucieus test. Mutat Res. 1975; 31: 9-15.

16. Agrawal RC, Kumar S. Prevention of Cyclophosphamide induced micronucleus formation in mouse bone marrow by Indole-3Carbinol. Food Chem Toxicol. 1998; 36(11): 975977.

17. Agrawal RC, Kumar S. Prevention of cyclophosphamide induced chromosomal aberrations in mouse bone marrow by Indole-3carbinol. Toxicol Lett.1999; 106(2-3): 137-141.

18. Agrawal RC, Pandey S. Evaluation of Anticarcinogenic activity of herbal medicinal plantAloe vera using skin papilloma model in Swiss albino mice. Int J Sci Res. 2013; 3: 1-6.

19. Ernst E, Pittler MH, Wider B, Boddy K. The Desktop Guide to Complementary and Alternative Medicine. Edinburgh: Elsevier Mosby; 2006.

20. Williams LD, Burdock GA, Shin E, Kim S, Jo $\mathrm{TH}$, Jones KN, Matulka RA. Safety studies conducted on a proprietary high-purity aloe vera inner leaf fillet preparation, Qmatrix. Regul Toxicol Pharmacol. 2010; 57(1): 90-98. 